\title{
KAMIEŃ NARZĘDZIEM PURYFIKACJI: KAMIENOWANIE STAROŻYTNYCH GREKóW JAKO RYTUAŁ OCZYSZCZENIA
}

\author{
Jan Skarbek-Kazanecki, janekdamal@orange.pl \\ Uniwersytet Łódzki \\ ul. Prezydenta Gabriela Narutowicza 65,90-131 Łódź
}

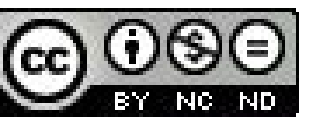

\begin{abstract}
STRESZCZENIE
Pojmowanie winy w starożytnej Grecji było zakorzenione w myśleniu symbolicznym, wszelkie zachowania związane z przewiną wykazywały zaś związek ze zmazą religijną (gr. miasma) oraz powszechnym lękiem przed tym, co nieczyste. Także kamienowanie, stanowiące jedną z metod wykonywania kary śmierci, odznaczało się specyfiką bliską obrzędom oczyszczenia. Celem niniejszego artykułu jest przedstawienie, występujących na gruncie greckim, religijnych konotacji aktu kamienowania - rytuału pomijanego milczeniem przez większość opracowań podejmujących temat greckiej zmazy - oraz puryfikacyjnego aspektu rzutu głazem.
\end{abstract}

Słowa kluczowe: kamienowanie, zmaza, puryfikacja, pharmakos, ekspulsja

\section{Stone as the purification tool: stoning of Ancient Greeks as the puryficatory practice}

\section{Abstract}

Understanding of guilt in Ancient Greece was deeply ingrained in symbolic language; particularly any behaviour that could be tied to offence was connected with the religious "stain" (grc. miasma) and the common fear of having contact with someone who is ",unclean". Also, the ritual of stoning, which was the main form of capital punishment, was one of the methods of purification. However, most publications on the issue of Greek stain exclude the question of stoning. The aim of the publication is to complete this omission and to show the religious connotation of the act of throwing stones in Ancient Greece.

Keywords: stoning, stain, purification, pharmakos, expulsion

W starożytnej Grecji istniały cztery sposoby wykonywania kary śmierci1: za pomocą kamieni, poprzez stracenie skazańców w przepaść (w Atenach nazywaną barathron²), przez tzw. apotympanismos, czyli - jak współcześnie uważa większość badaczy ${ }^{3}$ - przybicie aresztanta za pomocą żelaznych prętów do drewnianego słupa ${ }^{4}$, oraz za pośrednictwem cykuty (kōneion). Choć pozornie może się wydawać, że wszystkie one stosowane były zamiennie, wybór danej metody był ściśle uzależniony od charakteru przewiny, której dotyczył5; inaczej mówiąc: każdy z środków stracenia skazanego odznaczał się pewną specyfika, wyznaczającą okoliczności, w których jego użycie stawało się uprawnione. W wypadku kamienowania - metody najbardziej spektakularnej, ponadto najbliższej „kolektywnej wrażliwości” umysłowości archaicznych - kluczowy był charakter obrzędowy, korespondujący z wiarą starożytnych w magiczną zdolność kamieni do odwracania „nieczystości”.

Wyraził to Platon w Prawach, jednym ze swych ostatnich dzieł. Rozważając kwestię rozwiązań ustawodawczych dotyczących karania morderców, filozof głosit: „Nie ma bowiem innego oczyszczenia (katharsis) od zmazy (manthentos)

1 G. Herman, Morality and Behaviour in Democratic Athens: A Social History, Cambridge 2006, s. 292.

2 Z. Węclewski, Stownik grecko-polski, Warszawa 1874, s. 126, barathron: „otchłań, przepaść; zwł. przepaść skalista w Atenach w obwodzie gminy Hippothoontis, do której wskazanych na śmierć złoczyńców strącano”. Zob. podstawowe studium na temat barathronu jako metody wymierzania kary śmierci: A. Kerampoullos, Ho apotympanismos: symbolē archaiologikē eis tēen istorian tou poinikou dikaiou kai tēn laographian, Athina 1923 (streszczenie pracy Kerampoullosa: L. Gernet, Capital Punishment [w:] P. J. Rhodes (red.), Athenian Democracy, Oxford 2004, s. 137-141).

3 Podążających za: A. Kerampoullos, dz. cyt.

4 J. Fine, The Ancient Greeks: A Critical History, Cambridge/London 1983, s. 420: ,the criminal was fastened by means of five cramp irons to a wooden plank which was then set upright in the ground. It is uncertain whether the victim was left to die in agony after possibly days of exposure, or whether death was hastened by gradually tightening the iron collar". Zobacz także opis procedury apotympanismos u L. Gerneta, dz. cyt., s. 135-136.

5 Szczególnie ostatni z środków odbiegał od reszty: dobrowolny charakter zażycia trucizny stawiał skazanego w zupełnie innym świetle i okolicznościach niż publiczne egzekucje - łączące w sobie legalny wyrok sądowy (realizację przepisów prawnych) z publicznym linczem. L. Gernet sądzi nawet, że z tego powodu nie traktowano tej formy „kary ostatecznej” jako egzekucji we właściwym sensie tego słowa; postrzegana była ona raczej jako dopuszczalne, kontrolowane samobójstwo, L. Gernet, dz. cyt., s. 137. 
przelanej wspólnej krwi i nie da się ona zmyć, zanim dusza, która winna jest grzechu, śmiercią nie okupi śmierci" (872e-873a). Dlatego gdy sąd uzna, że ktoś jest winny zbrodni zabicia swojego krewnego, „,łludzy sądowi wraz z władzami poprowadzą skazańca na stracenie, po czym zawloką nagie zwłoki na wyznaczone poza miastem rozdroże, gdzie zbiorą się wszystkie władze państwowe i każdy z obecnych weźmie kamień i w imieniu państwa ciśnie w głowę trupa" (873b, przeł. M. Maykowska) ${ }^{6}$. Choć pomysły Platona nie stanowią bezpośredniego odbicia praw funkcjonujących w Atenach, nie zostały także nigdy zrealizowane w świecie helleńskim, opierają się na realnych przekonaniach Greków ${ }^{7}$ - stanowią tym samym istotną wskazówkę dla interpretacji charakteru kary śmierci, jakąjest kamienowanie.

W niniejszej pracy pragniemy, przyjmując za punkt wyjścia pojęcie „zmazy”, dostarczyć dowodów potwierdzających Platonskie intuicje; przyjrzeć się ceremonii kamienowania, greckim mniemaniom na temat właściwości kamienia oraz jego roli w życiu religijnym. W rozważaniach dotyczących metod karania śmiercią aspekt puryfikacyjny jest bowiem zupełnie pomijany bądź marginalizowany. Religijno-magicznych konotacji kamienia oraz czynności kamienowania jako środka przeciwdziałającego (religijnie rozumianej) przewinie nie docenił nawet Robert Parker, autor epokowego dzieła poświęconego greckiej nieczystości ${ }^{8}$; także najważniejsze monografie dotyczące greckiej religijności w opisach narzędzi puryfikacji pomijają kamien' 9 .

Liczymy tym samym, że uda nam się pokazać, iż akt przemocy, jakim było obrzucenie winnego zbrodni kamieniami, wśród starożytnych stymulowany był nie tylko przez specyficzne rozumienie postawy obywatelskiej i praktyki społecznej bądź przez negatywne zapędy mas, lecz także przez wierzenia i tradycje religijne.

\section{KAMIEŃ NARZĘDZIEM WALKI Z "POTĘGAMI ZŁOŚLIWYMI"}

Śledząc zachowane do naszych czasów teksty antyczne, możemy zaobserwować, że kamienie w wyobraźni Hellenów posiadały silne asocjacje magiczne; były one naznaczone właściwościami nadprzyrodzonymi, które ludzie chętnie wykorzystywali (bądź pragnęli wykorzystywać) we własnym interesie: przede wszystkim do łagodzenia wszelkich niepowodzeń oraz ochrony przed niepomyślnością. Zwrócił na to uwagę już James Frazer ${ }^{10}$, opisujący wiarę Hellenów w lecznicze kwalifikacje skał (np. leczenie ukąszeń węża, przyspieszanie gojenia się ran) ${ }^{11}$, zdolność do zapewniania poprzez głazy karmiącym piersią kobietom obfitości mleka oraz zwiększania zbiorów upraw w gospodarstwach rolnych ${ }^{12}$. Przekonanie o anormalnych cechach minerałów podzielali nawet filozofowie i uczeni ${ }^{13}$. I choć puryfikacyjne zdolności drzemiące w kamieniach nie wyczerpują bogactwa funkcji, które przypisywali im starożytni, wyczuwamy ich związek ze zmazą: nieczystościa, której znakiem są „,wszelkie choroby, cierpienia, śmierć, niepowodzenia"14, i której skutkom Grecy pragnęli przeciwdziałać poprzez działania magiczne.

Spośród grożących ludności archaicznej niepomyślności przedmiotem szczególnych obaw były działania wywoływane przez duchy, których namacalna obecność spędzała sen z powiek większości wyznawców popularnej magii ludowej. Kamienie, będąc przedmiotami magicznymi zapobiegającymi harcom potęg złośliwych ${ }^{15}$ oraz odpędzającymi quasi-ma-

6 Platon, Prawa, Warszawa 1997, s. 370-371.

7 Platon, najwyraźniej świadom swej bezsilności w walce z mniemaniami prostych ludzi, godzi się w Prawach na kompromis między konstruktem „idealnego państwa” zarysowanym w Rzeczpospolitej a zastaną przez siebie religią. Sam zdaje się zresztą informować o tym swoich czytelników zob. Platon, Prawa 738b-d (polski przekład: Warszawa 1997). Na temat związku Praw z praktyką prawno-religijną dawnej Attyki zob. R. Parker, Miasma. Pollution and Purification in early Greek Religion, Oxford 1983, s. 112-114.

8 Wspominając w swej pracy o kamienowaniu opisał je raczej jako formę publicznego linczu: ,just the kind of offence which was liable to provoke particularly violent forms of popular revenge", R. Parker, Miasma, dz. cyt., s. 194.

9 Zob. W. Burkert, Greek Religion, Oxford 1985, s. 76.

10 Przypuszczał on nawet, że „kamienie używane były jako amulety na długo, zanim zaczęto je nosić wyłącznie dla ozdoby”. J. Frazer, Złota Gałą́, Warszawa 1965, s. 56.

11 Zdaniem starożytnych kamienie nadawały się szczególnie do zwalczania przypadłości związanych z wyciekiem płynów ustrojowych z organizmu: łzawienia oczu, wszelkich krwotoków itp., Galen, De simplicium medicamentorum temperamentis ac facultatibus XII, s. 204; Orybazjusz, Collectiones Medicae XV, s. 26, [cyt. za:] S. Blakely, Myth, Ritual and Metallurgy in Ancient Greece and Recent Africa, Cambridge 2006, s. 141.

12 J. Frazer, Ztota Gałaź, dz. cyt., s. 56-57.

13 Tales z Miletu, dzięki „obserwacji kamienia magnetycznego i bursztynu przypisywał posiadanie duszy ciałom martwym”, Diogenes, Laertios I, 1, 24 (polski przekład: Diogenes, Laeortios, Żywoty i poglądy stynnych filozofów, Warszawa 2006), Galen zaś miał twierdzić, że ,bursztyn przyciaga strączki bobu”; Focjusz, Biblioteka, 279 (polski przekład: Focjusz, Biblioteka, t. IV: Kodeksy 238-248, Warszawa 1996); Platon w Timajosie, atakując nastawienie badawcze swoich kolegów-filozofów, zaprzecza zaś poglądowi, jakoby “bursztyny i magnesy” się przyciagały; Platon, Timajos 80d (polski przekład: Platon, Dialogi, T. 2 , Kęty 1999).

14 P. Ricoeur, Symbolika zła, Warszawa 1986, s. 29.

15 Określenie zaczerpnięte z pracy Wiktora Klingera, Nowogreckie pomniki przekleństwa i tradycje starożytne, „Przegląd Klasyczny” 1938, nr 4 (10), s. 724. 
terialne siły demoniczne, używane były przez Greków głównie poprzez rzucanie. Odwracający charakter tego gestu ilustruje Teofrastowy opis „człowieka zabobonnego", czyli odczuwającego lęk przed czynnikami nadprzyrodzonymi (Charaktery XVI3, przeł. I. Dąbska): „Jeśli mu łasica przez drogę przebiegnie, nie ruszy się z miejsca, dopóki ktoś inny go nie wyminie albo dopóki trzech kamieni na drogę nie rzuci"16 ${ }^{\prime \prime}$ W podobny sposób możemy rozpatrywać zwyczaj budowania kamiennych stosów nazywanych hermami (herma). Niektóre hermy powstawały spontanicznie ${ }^{17}$ : na przykład te przydrożne, prawdopodobnie zawdzięczające swoje istnienie zwyczajowi rzucania na rozstajach ścieżek - miejscach szczególnie poddanych działaniom nieżyczliwych mocy ${ }^{18}$ - drobnych głazów w celu złożenia ofiary bądź zminimalizowania ryzyka wejścia w kontakt z siłami nieprzychylnymi człowiekowi (zgodnie z tradycją hermy te przynależne były Hermesowi, patronowi dróg i opiekunowi podróżnych). Inne hermy budowano na grobach osób, których pośmiertnej działalności szczególnie się obawiano: ludzi przedwcześnie zmarłych (aōroi), brutalnie zamordowanych (biaiothanatoi), tych, którzy przed śmiercią nie weszli w związki małżeńskie (agamoi), oraz obcokrajowców $(k s e n o i)^{19}$. Jak zauważył Witold Klinger: "Jeżeli zmarły prosi wyraźnie, by na jego grób kamieni nie rzucać, to ma on widocznie powody tego się obawiać" ${ }^{\prime 2}$. Są nimi oczywiście moce magiczne drzemiące w tym „orężu”21. Przekonania te doskonale ilustruje fragment Antologii Palatyńskiej, w którym duch pochowanego zwraca się do przechodnia (hodoiporos) z prośbą o zaprzestanie obrzucania głazami należącego do niego kurhanu (VII 403, tłum. własne):

Lecz kamieni na kopiec grobowy, wędrowcze, nie staraj ty się ani rzucać, Ani innego nakłaniać [do tego]; zmarły dostał w udziale grób ${ }^{22}$.

Widać zatem, że kamień dla starożytnych stanowił narzędzie obrony przed i walki z demonicznymi potęgami. Za przejaw działania wrogich ludziom sił umysłowość archaiczna mogła zaś uznać wszystko, co wymykało się poznaniu i budziło grozę, choćby chorobę. Jak czytamy w traktacie przypisywanym Hipokratesowi OŚwiętej Chorobie (Peri hierēs nosou), współcześni autorowi Grecy wszelkie dolegliwości zdrowotne traktowali jako skutek działania istot nieśmiertelnych, chcących ukarać kogoś za ciążącą nad nim winę (aitia)23. Szczególnym lękiem otaczano zaś schorzenia psychicz$n^{24}$. Uprzedzenia narosłe wokół chorych skutkowały zaś nie tylko separacją społeczna, lecz także bezpośrednimi aktami przemocy skierowanymi w osobę doświadczającą zaburzeń psychicznych (stanowiących w przekonaniu ogółu skutek zmazy). Oczywistą praktyką odstraszania opętanego szaleństwem było rzucanie w niego kamieniami (Arystofanes, Ach. 1165-1168; Ar. Vespae 1486, 1491; Ar. Aves 524-5; Kallimach fr. 191.7925). W funkcji przeciwdziałania opętaniu rzut głazem pojawia się w tragedii Oszalały Herakles Eurypidesa, w której Atena (1004-1006, przeł. J. Łanowski):

16 Łasica dla starożytnych stanowiła zły omen, o czym informuje nas Księga Suda, hasło: oikoskopikon, [cyt. za:] J. Lawson, Modern Greek Folklore and Ancient Greek Religion: A Study in Survivals, Cambridge 2011, s. 327 oraz Apulejusz, Metamorfozy II, 25 (polski przekład: Apulejusz, Metamorfozy albo zloty osiol, Warszawa 1976), w których zwierzę to zostaje określone ,nieczystą bestią" (impurata bestia).

17 W Antologii Palatyńskiej XVI, 254 (polski przekład: Antologia Palatyńska, Warszawa 1978) możemy przeczytać: „Przechodzacy tędy ludzie usypali mnie - stos kamieni (lithinon sōron) Hermesowi poświęcony”. Dzięki Teofrastowi wiemy także, że istniał zwyczaj wylewania na „widywane na rozdrożach” kamienie oliwy: „[człowiek zabobonny] kiedy ma przejść obok kamieni błyszczących, które się widuje na rozdrożach, zlewa je oliwą z dzbanka i padłszy na kolana odprawia adoracje — potem dopiero odchodzi”; Charaktery XVI, 5 (polski przekład: Teofrast, Charaktery, Warszawa 1963).

18 Na rozstajach dróg pozostawiano także posiłki, Arystofanes, Plutos 594-597 (polski przekład: Arystofanes, Komedie: Sejm Kobiet, Plutos, Warszawa 1970) oraz drobne figurki dla Hekate, składano tam także ofiarę z poświęconego tej bogini psa, M. Dillon, Girls and Women In Classical Greek Religion, London/ New York 2002, s. 170.

19 K. Stears, The Times They Are A'Changing: Developments in Fiffh-Century Funerary Sculpture, [w:] G. L. Oliver (red.), The Epigraphy of Death: Studies in the History and Society of Greece and Rome, Liverpool 2000, s. 31; N. Demand, Birth, Death, and Motherhood in Classical Greece, Baltimore 1994, s. 7; J. Harrisson, Dreams and Dreaming in the Roman Empire: Cultural Memory and Imagination, London/New York 2013, s. 137.

20 W. Klinger, dz. cyt., s. 721.

21 Ciskanie kamieni na grób zmarłego stanowiło również przedmiot zniewagi, zob.: Eurypides, Elektra 324-328 (polski przekład: Eurypides, Tragedie, Warszawa 1980).

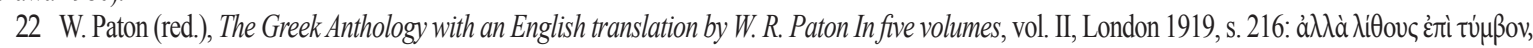

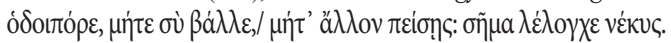

23 Zgodnie z powszechnymi przekonaniami wszelkie schorzenia stanowiły karę zsyłaną przez „matkę Bogów” (mētera Theōn), Posejdona bądź inne istoty nieśmiertelne (Hipokrates, O świętej chorobie, IV, 21-28); [cyt. za:] M. Jones (red.), Hippocrates with an english translation, Vol. II, London 1959; istniała także pewna grupa ludzi - wędrowni magowie (magoi) i uzdrawiacze posługujący się rytualnymi oczyszczeniami (kathartai) -, którzy w większości słów kierowanych do dotkniętych dolegliwościami przywoływali „[jakiegoś] boga bądź demona” (Hipokrates, O świętej chorobie IV, 5-6).

$24 \mathrm{Na}$ temat choroby psychicznej jako skutku działania istot nadprzyrodzonych zob. E. Dodds, Grecy i Irracjonalność, Bydgoszcz 2002, s. 61: „Ostatecznie wszystkie rodzaje zaburzeń umysłowych, nie wyłączając takich zjawisk, jak lunatyzm i delirium spowodowane wysoką gorączka, mogły być uważane za wynik działania duchów czy demonów".

25 J. Diggle, Theophrastus: Characters, Cambridge 2004, s. 375. 
Kamieniem (petron) ciska w pierś Heraklesowa, Żeby powstrzymać szał mordu i w sen go [Heraklesa - przyp.] Pograżyćc. $[. . .]^{26}$.

W kamienowaniu osoby dotkniętej szaleństwem odnajdujemy zatem, oprócz stereotypów prześladowczych oraz mechanizmów wykluczenia, echa wierzeń dotyczących oczyszczającej roli tej czynności²7.

Rys. 1. Czerwono-figurowy krater kielichowaty z Paestum. Paryż, Louvre (N 3157).

Zródło: opracowanie Mai Opałko na podstawie zdjęć eksponatu dostępnych na stronie internetowej muzeum² ${ }^{28}$.

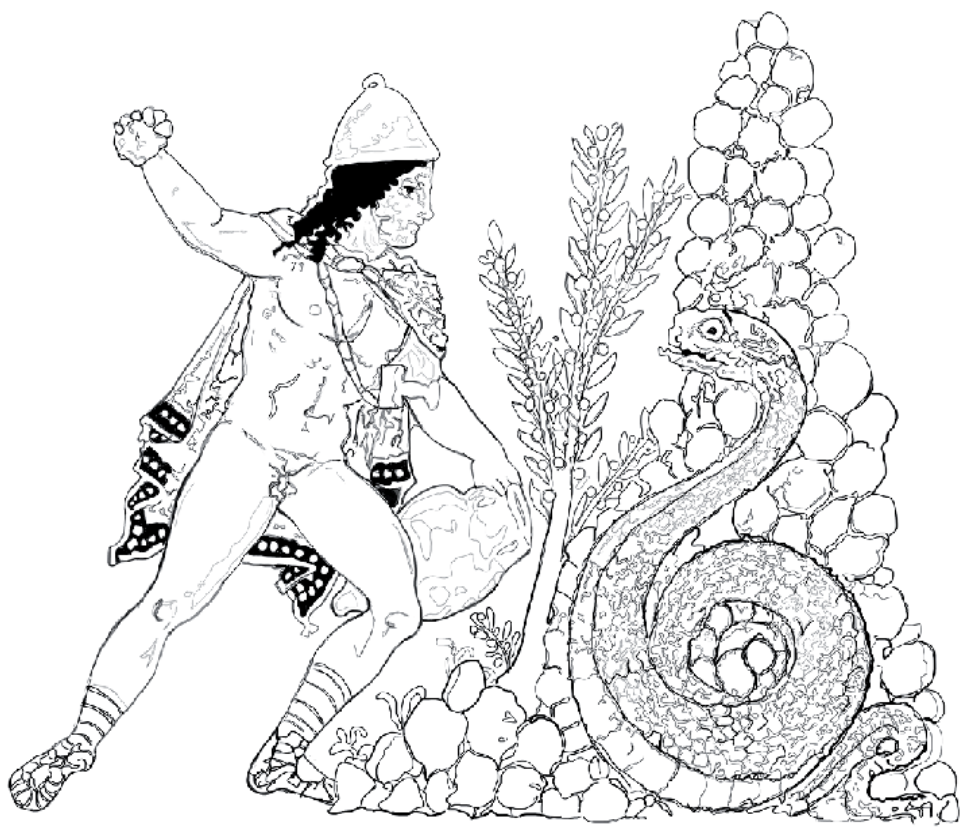

Gest rzutu głazem przewija się również w mitach: odnajdujemy go w opowieści przekazanej nam przez Pseudo-Apollodorusa (Bibliotheca 3. 22) oraz Pseudo-Hyginusa (Fabulae 178), zilustrowanej zaś na czerwono-figurowym kraterze z IV w. p.n.e. (znajdującym się w Luwrze), w której Kadmos kamieniem zabija Węża Ismejskiego (rys. 1)29. Potwory, wszelkie mitologiczne monstra jako istoty przekraczające i naruszające swą formą naturalny porządek stworzenia (kosmos) w czytelny sposób korespondują z symboliką zmazy: stanowią upostaciowienie wszelkich lęków narosłych wokół opozycji czyste-nieczyste. Kamień w owym micie ponownie występuje w formie narzędzia przeciwdziałającemu temu, co nieuporządkowane, zbrukane, skalane.

Ponadto posiadamy wartościowy opis Flawiusza Filostrata: zgodnie z nim przybyły do Efezu Apolloniusz z Tiany miał podjąć się walki z wybuchłą w tym miejscu zarazą poprzez przepędzenie pałętającego się po okolicy demona (daimōn) wcielonego w postać żebraka. W tym celu wydał on rozkaz ukamienowania ducha - źródła choroby (Żywot Apolloniusza z Tyany IV 10, przeł. I. Kania):

Zgromadziwszy tedy Efezjan rzekł: „Odwagi! Dziś jeszcze położę kres zarazie”, po czym cały tłum powiódł do teatru, gdzie ustawiony był posag bóstwa Odwracającego Plagi. Tam ujrzał kogoś o wyglądzie starca, żebraka, który zręcznie mrugając, udawał ślepca. Dźwigał on torbę dziadowska, w niej zaś kawałki chleba, odziany był w łachmany, twarz

26 Eurypides, Oszalały Herakles [w:] Tegoż, Tragedie, J. Łanowski (przeł.), Warszawa 1972, s. 254.

27 Dodatkowo symboliczny charakter czynności rzutu wzmacniają skojarzenia skały z twardością, nieczułością; ,przerażająca martwota świata kamieni”, o której pisał Károly Kerényi, zdaje się przeciwstawiać rozedrganiu, "skrajnej dynamice”, opętanego szaleństwem Heraklesa. Zob. Tegoż, Dionizos, Warszawa 2008, s. 192-193.

28 Apulian red-figure bell-krater, http://www.louvre.fr/en/oeuvre-notices/paestan-red-figure-calyx-krater, 10.12.2014.

29 Paris, Louvre, numer inwentarza N 3157. Analogiczne przedstawienia Kadmosa rzucającego kamieniem w węża znajdują się na terakotowym naczyniu z pierwszej połowy V w. p.n.e., London, British Museum, nr inwentarza D 7. kyliksie datowanym na 330 r. p.n.e. z Antikenmuseum und Sammlung Ludwig w Bazylei, BS 1421 oraz na kraterze z końca V w. p.n.e. z Metropolitan Museum of Art w Nowym Jorku, 22.139.11. Rzut kamieniem obecny jest także na korynckiej amforze z pierwszej poł. VI w. p.n.e. przedstawiającej Perseusza walczącego z potworem, Berlin, Staatliche Museen zu Berlin, nr inwentarza F 1652. 
miał brudną. Każąc Efezjanom otoczyć go zewsząd, [Apolloniusz] powiedział: „Weźcie tyle kamieni, ile możecie, i obrzućcie nimi tego nieprzyjaciela bogów ${ }^{\prime \prime 30}$.

Opowieść o Apolloniuszu z Tiany (pochodząca z początku III w. n.e. ${ }^{31}$ ) jest dla badaczy szczególnie interesująca. Oprócz magicznych asocjacji kamienia będącego narzędziem walki z groźnymi mocami ilustruje ona przywiązanie starożytnych Greków do typowego dla nich zwyczaju „oczyszczania miasta”: puryfikacji całej społeczności przez poświęcenie jej cząstki, wybranego obywatela, tzw. kozła ofiarnego, najczęściej nazywanego „pharmakosem” (pharmakos) ${ }^{32}$.

\section{KAMIENOWANIE METODĄ ODWRACANIA ZMAZY (MIASMA): EKSPULSJA PHARMAKOI}

Kim był grecki „kozioł ofiarny”, pharmakos? Trudno odpowiedzieć na to pytanie, gdyż rytuały, których był on bohaterem, choć znane w całej Grecjij33, przebiegały w różny sposób i opierały się na całkiem różnych kryteriach doboru ${ }^{34}$. Wspólny im wszystkim był co najwyżej katartyczny sens, czytelny dla wszystkich Greków. Upewniają nas w tym określenia, które nadawano ofiarom: wspomniany przydomek „,pharmakos" jest prawdopodobnie męską formą rzeczownika pharkamon ${ }^{35}$, który oznacza „lek, lekarstwo, trucizna, czarodziejski środek" ${ }^{\prime \prime 3}$, używany niekiedy zamiennie z nim katharma, czyli „,brud, śmieci, odrzutki, wyrzutek, ofiara oczyszczalna” ${ }^{37}$, wykazuje zaś etymologiczny związek ze słynnym katharsis „,oczyszczenie” oraz przymiotnikiem katharos, „, wolny od brudu"38. W Bibliotece Focjusza I (279, przeł. O. Jurewicz), w wyciagu z Chresomatii Helladiusa czytamy zaś:

Zgodnie ze zwyczajem Ateńczycy wybierali dwa kozły ofiarne, jednego dla mężczyzn, drugiego dla kobiet, i wypędzali, by w ten sposób dokonać oczyszczenia. (...) To oczyszczenie zażegnywało choroby zakaźne. Zaczęło się ono od Kreteńczyka Androgeosa, który zginął w Atenach gwałtowną śmiercia; na Ateńczyków spadła zaraza i odtąd weszło na stałe w zwyczaj oczyszczanie miasta za pomocą kozłów ofiarnych (pharmakoi ${ }^{39}$.

Jak widzimy, dla Greków sednem poświęcenia pharmakosa było zlikwidowanie, poprzez obrzędowe działanie, spoczywającej na całej społeczności zmazy, symboliczne wyrzucenie zła ${ }^{40}$. Potrzeba ta odzywała się szczególnie w obliczu niespodziewanych zagrożeń, nagłych niebezpieczeństw spadających na daną polis ${ }^{41}$ : epidemii, głodu, wojny ${ }^{42}$. Oprócz tego dochodziła ona do głosu podczas corocznych uroczystości ku czci Apollina (w Atenach nazywanych Thargelia ${ }^{43}$ ). Metodą walki z religijnym skalaniem nie był jedynie obyczaj wypędzania wybranej osoby, lecz także miotanie w nią

30 Flawiusz Filostrat, Żywot Apolloniusza z Tyany, Kraków 1997.

31 M. Dzielska, Przedmowa [w:] Flawiusz Filostrat, Żywot Apolloniusza z Tyany, dz. cyt., s. 7.

32 Opowieść o ukamienowaniu starca-żebraka stanowi doskonałąilustrację procesu marginalizacji, dyskryminacji społecznej oraz alienacji od różnych sfer życia zbiorowego jednostki dotkniętej ubóstwem. Każdy ubogi, jako osoba podejizana moralnie, odseparowana od wspólnoty, będąca tym samym potencjalnym zarzewiem zarazy, nadawał się idealnie do roli „kozła ofiarnego". Dlatego, jak ukazują to scholia do Rycerzy Arystofanesa, 1136c (według wydania: D. Jones, N. Wilson (red.), Scholia in Aristophanis Equites, Groningen 1969), jako pharmakosów często wybierano najbiedniejszych mieszkańców miasta (przekład własny): „Przez «[karmionych] na koszt państwowy» (dēmosious) rozumie on tych, którzy są nazywani pharmakoi - tych właśnie, którzy oczyszczaja miasta poprzez własną śmierć. Ateńczycy, w okresie nadciagającego na polis zagrożenia - mam na myśli głód lub jakieś [inne nieszczęście] tego rodzaju - karmili tych, którzy byli nadmiernie nisko urodzeni (agenneis), nędzarzy (penētas) oraz [ludzi] bezużytecznych i składali ich w ofierze w celu oczyszczenia (katharthēnai) siebie samych od zmazy i skalania, a także odnalezienia lekarstwa na wiszące nad nimi zło".

33 Istnieją opisy pozwalające na wskazanie Aten, Ionii, Abdery, Massilii oraz Cheronei (Plutarch, Quaestiones Convivales 693e, polski przekład: Plutarch, Moralia. dz. cyt.) jako miejsc, w których z całą pewnością praktykowano ryt ekspulsji pharmakosa. Ponadto możemy przypuszczać, że obyczaj ten znany był w Efezie, skąd pochodził Hipponaks, poeta, którego utwory stanowią najstarsze źródło danych na temat greckiego rytuału „kozła ofiarnego”.

34 Ksiażek i artykułów podejmujących wątek wypędzania pharmakosa napisano wiele, zob. np. J. Bremmer, Scapegoat Rituals in Ancient Greece, „Harvard Studies in Classical Philology” 1983, nr 87, s. 299-320; W. Burkert, Greek Religion, dz. cyt., s. 82-84; R. Girard, Koziol ofiarny, Łódź 1991.

35 P. Chantraine, Dictionnaire étymologique de la langue grecque. Histoire des mots, Paris 1968, s. 1178, hasło: pharmakos.

36 Z. Węclewski, dz. cyt., s. 662.

37 Tamże, s. 360 .

38 P. Chantraine, dz. cyt., s. 479; É. Boisacq, Dictionnaire étymologique de la langue grecque, Heidelberg/Paris 1916, s. 389-390.

39 Focjusz, Biblioteka, O. Jurewicz (przel.), t. 4: Kodeksy 238-248, Warszawa 1996.

40 W. Lengauer, Religijność starożytnych Greków, Warszawa 1994, s. 102: „Ofiara nie jest tu poświęcona bogu, jest tym, czego nalezy się pozbyć”; R. Parker, Miasma, dz. cyt., s. 257: „The pharmakos ceases to be more vehicle on to which the ills of the comunity are loaded by a mechanical process of transference, and becomes instead, through his crime, the actual cause of whatever affliction is being suffered"; D. Hughes, Human Sacrifice in Ancient Greece, New York 2000, s. 157: „The ceremony culminated in the stoning of a pharmakos, but the purpose was not to kill but to drive him over the boundaries of the city".

41 R. Girard, Koziol ofiarny, dz. cyt., s. 13: „Jeśli epidemia rzeczywiście wybucha, istnieje duże prawdopodobieństwo, że zbudzi uśpione przesądy”.

42 Ilustruje to doskonale fragment Chiliady V $726-737$ (R. Rosół (przel.), „Nowy Filomata” 2007, nr 11, s.190): „Był w dawnych czasach wyrzutek, kozłem zwany ofiarnym/ Na miasto kiedy los spadał z gniewu boskiego marny,/ Czy to głód, czy to zaraza, czy jeszcze coś innego,/ Wiedziono jako ofiarę ze wszystkich najbrzydszego,/ By miasto klęską dotknięte oczyścić i uzdrowić".

43 Na temat attyckich Thargeliów zob. R. Parker, Polytheism and Society at Athens, Oxford 2009, s. 481-483. 
omawianym środkiem odwracania nieczystości - kamieniem.

W wyjaśnieniu hasła „pharmakos" w Stowniku do dziesięciu mówców żyjącego prawdopodobnie w II w. n.e. Harpokrationa z Aleksandrii (przeł. R. Rosół) czytamy:

Pharmakos: Lizjasz używa tego słowa w mowie Przeciw bezbożności Andokidesa, jeśli jest autentyczna. W Atenach podczas Targeliów wypędzano z miasta dwóch mężczyzn mających być ofiarami oczyszczalnymi, jednego za mężczyzn, drugiego za kobiety. Istros w pierwszej księdze Epifanii Apollona [FGrHist 334 F 50] mówi, że istnieje imię własne Pharmakos; człowiek o tym imieniu ukradłszy święte naczynia Apollona został schwytany i ukamienowany przez ludzi Achillesa, czego naśladownictwem są praktyki podczas Targeliów ${ }^{4}$.

Choć przedstawionej przez aleksandryjskiego filologa opowieści dotyczącej źródeł rytuału nie możemy traktować jako wiedzy historycznej sensu stricto, przewrotnie zdradza nam ona więcej niż autor zamierzał. Służąc, jak każdy „mit ajtiologiczny", uzasadnieniu wiary w pewne wartości bądź działania, ujawnia ona istotność zwyczaju miotania kamykami w „kozła ofiarnego". Jak wynika zatem z opisu, ceremonia ta w okresie klasycznym polegała na schwytaniu dwóch pharmakoi (oczywiście płci męskiej), następnie przepędzeniu ich z miasta i obrzuceniu głazami (niekoniecznie z intencją ich zabicia), zapewne w towarzystwie obelg, zniewag, chłost ${ }^{45}$ oraz muzyki ${ }^{46}$. Kamienowanie występowało także podczas analogicznego święta obchodzonego w Abderze, stanowiąc jego punkt kulminacyjny: jak czytamy w komentarzu do utworu Ibis Owidiusza (w. 467-468, przekład własny): „Obywatele Abdery mówia, że raz w roku przechodzą publiczne oczyszczenie i że zabijają kamieniami zakupionego człowieka (emptum hominem), przeznaczonego na ofiarę w imieniu wszystkich". Kallimach we fr. 90 informuje nas zaś, iż karmiono w tym miejscu wystawnymi potrawami jakiegoś „,kupionego człowieka” (ōnētos anthrōpos, chodzi oczywiście o niewolnika ${ }^{47}$ ), aby następnie doprowadzić tegoż do murów miasta i wygnać poza ich granice poprzez obrzucanie go drobnymi kamykami. Utrzymywanie przez daną polis osoby, która zaoferowała się do roli „kkozła ofiarnego", było praktykowane ponadto w innych miastach greckich: np. w Massilii, gdzie pharmakos żywił się z pieniędzy publicznych przez okres roku (alebatur anno toto), w odpowiednim zaś czasie „zostawał zabity kamieniami przez społeczność” (saxis occidebatur a populo, Lactantius Placidus, Comm. in Stat. Theb. 10.793), a - jeśli wierzyć intuicjom Todda M. Comptona ${ }^{48}$ - także w niektórych miastach Jońskich, o czym miałyby świadczyć poniższe heksametry Hipponaksa (fr. 128 West / 126 Degani = Atenajos, Deipnosophistae 15.55, przekład własny):

Muzo, opowiedz mi o synu Euromedonta, który -jak Charybda morska z nożem w odwłoku -żre bezwstydnie. [Powiedz] jak zginie zły śmiercią nędzną kamieniem [trafiony] [z woli] zgromadzenia ludu nad brzegiem morza jałowym ${ }^{49}$.

Przedstawione dowody na obecność kamienowania podczas rytu ekspulsji pokazuja że kamienie lub czynność rzucania nimi w "kozły ofiarne” stanowiły dla Greków jedno z narzędzi bądź metod puryfikacji polis. Pharmakos, dzięki przejęciu wszelkich złych uczynków (czyli źródeł zmazy) od reszty społeczności, miał położyć kres nieszczęściu ${ }^{50}$. Przywrócenie zakłóconego ładu nie mogło jednakże zadziać się samoistnie; wymagało ono czynności usuwającej „nieczystości” skumulowane w ofierze: jakiegoś gestu wzmocnionego czymś równie substancjalnym, co sama zmaza - w tym wypadku kamieniem, czyli uświęconym orężem ludzkości w walce ze wszystkim, co wymyka się refleksji i co „kala jak brud"51.

44 R. Rosół, Pochodzenie rytuału „,kozła ofiarnego” w Starożytnej Grecji, „Meander” nr 3-4 (2006), s. 280-289.

45 Obecność chłosty w omawianym rycie ekspulsji potwierdza najstarszy zachowany utwór zawierający wątek pharmakosa: fragment jambów Hipponaksa (fr. 4-6): „Oczyścić miasto, gnanym być witkami./ Na mrozie pędząc, niczym kozła ofiarnego,/ Witkami figi cebulą morską chłoszcząc. Uczynić z niego trzeba kozła ofiarnego". J. Danielowicz (przel.), Liryka Starożytnej Grecji, Wrocław 1987, s. 272.

46 Istniały specjalne melodie wykorzystywane podczas tej uroczystości, nazywane kradiēs nomos, zob. Hezychiusz, Leksykon, hasło: kradiēs nomos (wg wyd. Hesychii Alexandrini lexicon, ed. M. Schmidt, Jenae 1858-1868, s. 915).

47 Przymiotnik ōnētos często występuje w kontekście „niewolnictwa”, e.g. w Królu Edypie, w. 1123. Niewolników jako pharmakoi używano także w ojczyźnie Plutarcha, Cheronei, Quaestiones Convivales 693e (polski przekład: Plutarch, Moralia, dz. cyt.).

48 T. Compton, Victim of the Muses. Poet as Scapegoat, Warrior and Hero in Greco-Roman and Indo-European Myth and History, Washington 2006, s. 66.

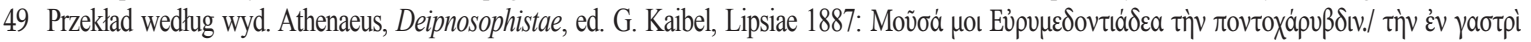

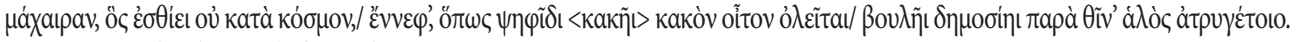

50 R. Girard, Koziol ofiarny, dz. cyt., s. 66, 68.

51 P. Ricoeur, dz. cyt., s. 27. 


\section{OsĄd NAd HERMESEM: KARA PRAwNA OCZYSZCZENIEM}

Oczyszczający charakter kamienowania zbrodniarza poświadcza także mit poświęcony sądowi bogów nad Hermesem. Jak podają Antyklides (FGrHist 140 F 19) oraz żyjący w połowie V w. p.n.e. logograf Ksantos (FGrHist 765 F 29)52, bogowie olimpijscy zaniepokojeni pierwszym morderstwem dokonanym przez nieśmiertelnego - zabiciem potwora Argosa - chcieli osądzić Hermesa; ze strachu przed Dzeusem, „zleceniodawcą” mordu, poprzestali na obrzuceniu odpowiedzialnego zbrodni kamykami służącymi do głosowania (psēphoi). Podanie to przekazują nam także scholia do Odysei Homera (XVI, 471)53, w których powiada się, że rzucone kamienie miały odwrócić zmazę (agos) i zwolnić boga z winy zabójstwa (androphonia).

Opisany mit pełnił wiele funkcji: tłumaczył związek Hermesa ze stosami kamieni, poprzez postać potwora Argosa wyjaśniał epitet, którym Hermes bywał określany w utworach homeryckich: Argeiphontēs (tu rozumiany jako „zabójca Argosa" ${ }^{54}$, przede wszystkim jednak uprawomocniał praktykę kamienowania. Jak pisze bowiem Mircea Eliade:

„W sumie, mity opisują różnorodne i czasem dramatyczne wtargnięcia sfery sacrum (...) w obręb Świata. To na tym wtargnięciu ufundowany jest Świat i właśnie za jego sprawą jest on taki, jakim dziś go widzimy. (...) Mit, relacjonując gesta Istot Nadnaturalnych oraz inne przejawy ich świętej potęgi, staje się modelem pouczającym o wszelkich znaczących czynnościach ludzkich" ${ }^{\prime \prime 5}$.

Podobne „pouczenie” mogło być szczególnie cenne w okresie, w którym obrzucanie innego człowieka, choćby winnego zbrodni, głazami ze względu na swą brutalność mogło budzić pewne etyczne wątpliwości. Na mocy mitu praktyka kamienowania stawała się jednakże imitatio dei: odtwarzaniem pierwotnego gestu bóstwa lub bóstw, powtarzaniem aktu wykonanego - jak powiada Eliade - „w owym czasie”, ",u początku” (in illo tempore, ab origine, ab initio), tym samym gwarantującego uczestnictwo w sacrum.

Zdarzeniem kulminacyjnym w micie jest nałożenie na Hermesa kary. Pomsta, dla społeczeństw archaicznych stanowiąca nieuchronne następstwo „nieczystości" ${ }^{156}$, nie mogła być jednakże jedynie powtórzeniem zbrodni: wymagała pewnej instytucjonalizacji, utrzymania choćby pozorów sprawiedliwości. Obrzucenie głazami zabójcy Argosa, choć wyglądające na spontaniczny akt przemocy zbiorowej, odbywa się zatem w ramach legalnej procedury „,sądowej”.

Identycznie rzecz przedstawiała się w wypadku rzeczywistych kamienowań Greków. Kara śmierci wykonywana za pomocą głazów była linczem, który zostawał spełniony - jak powiada Hipponaks w cytowanym fragmencie - „[Z woli] zgromadzenia ludu" (boulēi dēmosiè)), granica między prawem a samosądem w wypadku takiego wyroku była zatem płynna $^{57}$; skoro zaś pierwotną intencją kamienowania było usunięcie zmazy, karę tę nakładano przede wszystkim na sprawców przestępstw sakralnych: zbezczeszczenia świątyń, wejścia w kontakt ze sferą tabu itp. Jak podaje Pauzaniasz, Hellenowie nie wzbraniali się nawet przed ukamienowaniem dzieci, które zawiniły, próbując podczas zabawy obwiązać

52 [Cyt. za:] W. Burkert, Homo Necans. The Anthropology of Ancient Greek. Sacrifal Ritual and Myth, London 1983, s. 165.

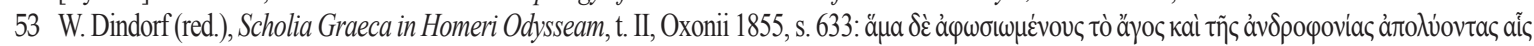

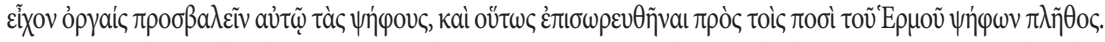

54 Walter Burkert (Homo Necans, dz. cyt., s. 165) oraz Martin West (Indo-European Poetry and Myth, Oxford 2007, s. 82) sądza, że pierwotnie pierwszy człon w epitetu-złożenia miał sens lokatywny, tym samym Argeiphontēs domyślnie oznaczał „zabójcę z Argos”.

55 M. Eliade, Struktura mitów, Warszawa 1998, s. 11-12.

56 P. Ricoeur, dz. cyt., s. 32.

57 Grecy wykorzystywali różne środki społecznej kontroli dużo „elastyczniej” niż ramy współczesnego „państwa prawa” pozwalałyby na to, S. Forksyde, Street theatre and popular justice in Ancient Greece: shaming, stoning and starving offenders inside and outside the courts, „Past and Present" 2008, nr 201, s. 6. Istniało na przykład przyzwolenie o mocy prawnej (o ewidentnie przeddemokratycznym rodowodzie) na zabicie nakrytego cudzołożnika. Częściej jednakże poddawano schwytanego publicznemu upokorzeniu, połączonemu niekiedy z zadawaniem fizycznego cierpienia, np.

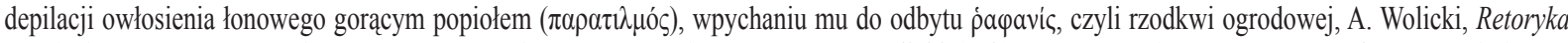
i cudzołóstwo. Uwagi o „Obronie w sprawie zabójstwa Eratosthenesa” [w:] A. Wolicki (red.), TIMAI. Studia poświęcone profesorowi Włodzimierzowi Lengauerowi przez uczniów i młodszych kolegów z okazji Jego 60. urodzin, Warszawa 2009, s. 195-196. Także w wypadku legalnej procedury

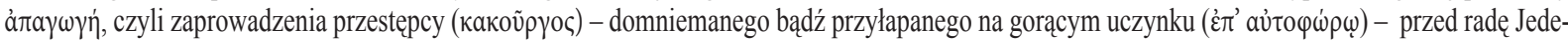
nastu, istniał szereg okazji do jego zbiorowej zniewagi: oskarżony zostawał schwytany na ulicy, prawdopodobnie przez sąsiadów i członków własnego demu; następowała parada ulicami Aten z aresztantem na czele do siedzimy rady, ta zaś mogła przeprowadzić jego egzekucję w trybie doraźnym bądź, w wypadku nieprzyznania się do winy, stawić go przed sądem. Nawet w drugim z nakreślonych wypadków wyrok nie musiał być jednakże zgodny z literą prawa, ateńscy sędziowie głosowali bowiem ,anonimowo i zbiorowo, a to oznacza, że w wydawaniu wyroku zostawali sam na sam ze swoim sumieniem". Wykonanie orzeczonej przez sąd kary odbywało się zaś na agorze, zatem w miejscu dostępnym oczom wszystkich zainteresowanych (co musiało być głęboko upokarzające dla skazanego); możemy także przypuszczać, że również ten proceder nie był wolny od publicznych zniewag. L. Gernet, dz. cyt., s. 153, V. J. Hunter, Policing Athens: Social Control in the Attic Lawsuits, Princeton 1994, s. 177. 
liną statuę Artemidy w jej świątyni58. Podobnie moglibyśmy rozpatrywać kamienowanie zdrajców i dezerterów w wojsku. Wybór sposobu kary - przez wzgląd na dostępność wśród żołnierzy innych narzędzi zadawania krzywdy -nie mógł być przypadkowy ${ }^{59}$. Współpraca z wrogiem czy unikanie walki stanowiło dla Greków nie tylko pogwałcenie disciplina militaris, dyscypliny wojskowej, lecz także wystąpienie przeciwko porządkowi bogów: pogwałcenie modlitwy i ofiary przed wojną ${ }^{60}$, które mogło spowodować nieprzychylność sił boskich. Przezorność wymagała zatem czynności odwracającej przewinienie. Także wszelki zamach na wolność, ustrój demokratycznych poleis greckich, odbierano jako zmazę religijną godną kary w postaci kamienowania. Ilustruje to opowieść przekazana nam przez Plutarcha dotycząca usunięcia „skalania” (agos) z uczestników sprzysiężenia Kylona - próby przejęcia tyrańskiej władzy w Atenach (Żywoty Rówonoległe: Solon, XII, 1, przeł. L. Trzcionkowski):

Zmaza kylońska (to Kulōneion agos) wprowadzała zamieszanie do miasta od dawna, to znaczy od czasu, gdy Megakles, który sprawował urząd archonta, przekonał uczestników sprzysiężenia Kylona, błagalników bogini, aby zeszli z akropolu i oddali się pod sąd. Ci przywiązali do posąu uprzędzioną nić i trzymając ja zaczęli schodzić, aż znaleźli się koło przybytku Czcigodnych Bogiń, gdzie nić samorzutnie się urwała. Wówczas Megakles w otoczeniu współrządzących ruszył, by ich pochwycić pod pozorem, że bogini odmówiła ochrony błagalnikom. Tych, którzy pozostali na zewnątrz, ukamienowali, a tych, którzy schronili się u ołtarzy - zarżnęli; wypuścili jedynie tych, co uciekli się pod opiekę żon archontów jako błagalnicy ${ }^{61}$.

Skromna ilość podań dotyczących wyroków sądowych, szczególnie opisów kamienowań pochodzących z okresu klasycznego, nie pozwala nam na dalszą analizę. Informacje o wykonaniu kary śmierci przy użyciu kamienia rzadko kiedy dostarczają nam kontekstu pozwalającego na przypisanie charakteru przewiny do obranej kary. Wiemy jednakże, że wątek zmazy nie zniknął z „dyskursu prawnego" Ateńczyków wraz z racjonalizacją ich religii oraz zmianą sposobu funkcjonowania struktur państwowych w V i IV w. p.n.e. W mowie politycznej Lizjasza (Przeciwko Andokidesowi o bezbożnośc) datowanej na r. 399 p.n.e. przestroga przed „nienawiścią bogów”, która może spaść na polis w wypadku zignorowania „nieczystości" wywołanej naruszeniem praw sakralnych, stanowi wręcz ostateczny argument przeciwko oskarżone$\mathrm{mu}^{62}$. Możemy zatem przypuszczać, że kamienowanie w Grecji było praktykowane jako środek odwracania zmazy także w okresie klasycznym oraz epoce hellenistycznej: zrozumiałość takiego wykorzystania kamienia poświadcza przytaczany wcześniej fragment Żywotu Apolloniusza z Tiany, tekstu z III w. n.e., w którym obrzucenie nędzarza-demona staje się środkiem oczyszczenia miasta.

Kwestią otwartą pozostaje także odpowiedź na pytanie o relację prawa sakralnego do linczu. W toku badania „religioznawczego" nie powinniśmy bowiem zapominać, iż kamienowanie było przede wszystkim formą przemocy. To, co dla starożytnych stanowiło oczyszczenie, dla nas jawi się jako akt agresji; pharmakos, dla Greków będący „lekarstwem” na zmazę, dla nas jest "kozłem ofiarnym" ${ }^{63}$ - ofiarą stereotypów prześladowczych, zacietrzewienia religijnego oraz powszechnego przyzwolenia na gwałt i terror. Na ile sami starożytni mieli tego świadomość, albo na ile elity świata politycznego dawnej Grecji posługiwały się wierzeniami prostych ludzi do osiągania własnych celów, nie sposób jednakże odpowiedzieć w tym studium. Przedstawione wyniki badań pozwalają nam jedynie stwierdzić, że religijny sens kamienowania, ufundowany na rycie ekspulsji pharmakosa oraz na wierze w bezpośrednią zdolność głazów do zwalczania sił nieczystych, odbijał się na porządku prawnym, wyznaczając niekiedy zakres i funkcję tego aktu rozumianego jako kara śmierci.

58 Pauzaniasz, Wẹdrówka po Helladzie VIII, 23, 6-7 (polski przekład: Pauzaniasz, Wẹdrówka po Helladzie , t. I-III, Wrocław 1973-89), „Oto kilkoro pacholąt, o których liczbie pamięć zaginęła, bawiło się pewnego razu wokół przybytku bogini. Przypadkiem znalazły kawałek liny, obwiązały szyję posagu bogini, wołając przy tym, że duszą Artemidę. Mieszkańcy Kafyaj odkrywszy ten czyn, ukamienowali dzieci”.

59 Fakt ten zastanawiał już A. Peace'a, Notes on Stoning among the Greeks and Romans ,Transactions and Proceedings of the American Philological Association" 1907, nr 38, s. 6 .

60 B. Snell, Szenen aus griechischen Dramen, Berlin 1971, s. 5.

61 Plutarch, Solon, L. Trzcionkowski (przeł.), [w:] Tegoż, Żywoty Równoległe, t. 2, K. Korus, L. Trzcionkowski (przeł.), Warszawa 2005.

62 Lizjasz, Mowy VI $52-54$ (polski przekład: Lizjasz, Mowy, Kraków 1998): „Ów przyznał się do swoich czynów. Co więcej, przez przekroczenie ustanowionego przez was prawa, które mu jako zbrodniarzowi zabrania wstępu do świątýn, naruszył te wszystkie zakazy (...). Komu wolno na to pozwolić? Kto z przyjaciół, krewnych czy członków tego samego demu, oddając mu po kryjomu usługę, zechce jawnie narazić się na nienawiść bogów? Musicie zatem uświadomić sobie, że wymierzając dzisiaj karę Andokidesowi i usuwając go, oczyszczacie miasto, dokonujecie kultowego zmycia zmazy, pozbywacie się skazańca jakby pokutnej ofiary (pharmakos), uwalniacie się od potępieńca, bo on jest tym wszystkim w jednej osobie".

63 R. Girard, Koziol ofiarny, dz. cyt., s. 180. 


\section{TEKSTY ŹRÓDŁOWE:}

[1] Antologia Palatyńska, Warszawa 1978

[2] Burnet J. (red.), Platonis Opera, Oxford 1903

[3] Dindorfius G. (red.), Scholia Graeca In Homeri Odysseam, t. II, Oxonii 1855

[4] Dindorf W. (red.), Lexicon In decemoratores Atticos, Oxford 1853

[5] Diogenes Laertios, Żywoty i poglady stynnych filozofów, Warszawa 2006

[6] Flawiusz Filostrat, Żywot Apolloniusza z Tyany, Kraków 1997

[7] Focjusz, Biblioteka, T. IV: Kodeksy 238-248, Warszawa 1996

[8] Hipponaks [w:] Danielowicz J. (red.), Liryka Starożytnej Grecji, Wrocław 1987

[9] Jones M. (red.), Hippocrates with an english translation, vol. II, London 1959

[10] Jones D., Wilson N. (red.), Scholia in Aristophanis Equites, Groningen 1969

[11] Kaibel G. (red.), Athenaeus, Deipnosophistae, Lipsiae 1887

[12] Lamb W. (red.), Lysias with an English translation by W. R. M. Lamb, London 1930

[13] Lizjasz, Mowy, Kraków 1998

[14] Murray G. (red.), Euripidis Fabulae, vol. II, Oxford 1913

[15] Paton W. (red.), The Greek Anthology with an English translation by W. R. Paton In five volumes, vol. II, London 1919

[16] Pauzaniasz, Wędrówka po Helladzie, t. I-III, Wrocław 1973-89

[17] Pfeiffer R. (red.), Callimachus, vol. I: Fragmenta, Oxford 1949

[18] Platon, Państwo, Prawa (VII Ksiag), Warszawa 2001

[19] Platon, Prawa, M. Maykowska (przeł.), Warszawa 1997

[20] Plutarch, Żywoty Równoległe, t. II, Warszawa 2005

[21] Teofrast, Charaktery, Warszawa 1963

\section{Bibliografia:}

[22] Blakely S., Myth, Ritual and Metallurgy in Ancient Greece and Recent Africa, Cambridge 2006

[23] Boisacq É., Dictionnaire étymologique de la langue grecque, Heidelberg/Paris 1916

[24] Bremmer J., Scapegoat Rituals in Ancient Greece, „Harvard Studies in Classical Philology” 1983, nr 87

[25] Burkert W., Greek Religion, Oxford 1985

[26] Burkert W., Homo Necans. The Anthropology of Ancient Greek. Sacrifal Ritual and Myth, London 1983

[27] Chantraine P., Dictionnaire étymologique de la langue grecque. Histoire des mots, Paris 1968

[28] Compton T., Victim of the Muses. Poet as Scapegoat, Warrior and Hero in Greco-Roman and Indo-European Myth and History, Washington 2006

[29] Demand N., Birth, Death, and Motherhood in Classical Greece, Baltimore 1994

[30] Diggle J., Theophrastus: Characters, Cambridge 2004

[31] Dillon M., Girls and Women in Classical Greek Religion, London/New York 2002

[32] Dodds E., Grecy i Irracjonalność, Bydgoszcz 2002

[33] Dzielska M., Przedmowa [w:] Flawiusz Filostrat, Żywot Apolloniusza z Tyany, Kraków 1997

[34] Eliade M., Struktura mitów, Warszawa 1998

[35] Fine J. V.A., The Ancient Greeks: A Critical History, Cambridge/London 1983

[36] Forksyde S., Street theatre and popular justice in Ancient Greece: shaming, stoning and starving offenders inside and outside the courts, „Past and Present” 2008 , nr 201

[37] Frazer J., Ztota Gałą́, Warszawa 1965

[38] Gernet L., Capital Punishment, [w:] Rhodes P. J. (red.), Athenian Democracy, Oxford2004

[39] Girard R., Kozioł ofiarny, Łódź 1991

[40] Harrisson J., Dreams and Dreaming in the Roman Empire: Cultural Memory and Imagination, London 2013

[41] Herman G., Morality and Behaviour in Democratic Athens: A Social History, Cambridge 2006

[42] Hughes D., Human Sacrifice in Ancient Greece, New York 2000

[43] Kerampoullos A. D., Ho apotympanismos: symbolē archaiologikē eis tēn istorian tou poinikou dikaiou kai tēn laographian, Athina 1923

[44] Kerényi K., Dionizos, Warszawa 2008

[45] Klinger W., Nowogreckie pomniki przekleństwa i tradycje starożytne, „Przegląd Klasyczny” 1938, nr 4 (10)

[46] Lawson J., Modern Greek Folklore and Ancient Greek Religion: A Study in Survivals, Cambridge 2011

[47] Lengauer W., Religijność starożytnych Greków, Warszawa 1994

[48] Parker R., Miasma. Pollution and Purification In Elary Greek Religion, Oxford 1983

[49] Pease A. S., Notes on Stoning among the Greeks and Romans, „Iransactions and Proceedings of the American Philological Association” 1907, no. 38

[50] Rosół R., Pochodzenie rytuału „kozła ofiarnego" w Starożytnej Grecji, „,Meander” 2006, nr 3-4

[51] Ricoeur P., Symbolika zła, Warszawa 1986

[52] Snell B., Szenen aus griechischen Dramen, Berlin 1971

[53] Stears K., The Times They Are A'Changing: Developments in Fifth-Century Funerary Sculpture [w:] Oliver G. L. (red.), The Epigraphy of Death: Studies in the History and Society of Greece and Rome, Liverpool 2000

[54] West M., Indo-European Poetry and Myth, Oxford 2007

[55] Węclewski Z., Stownik grecko-polski, Warszawa 1874

\section{NetOgRAFia:}

[56] apulian red-figure bell-krater, http://www.louvre.fr/en/oeuvre-notices/paestan-red-figure-calyx-krater, 10.12.2014 